\title{
Control of Soilborne Pathogenic Fungi in Fields of Sweet Onion
}

Donald R. Sumner and Ronald D. Gitaitis, Coastal Plain Experiment Station, and J. Danny Gay, Rural Development Center, Department of Plant Pathology, Tifton, GA 31793-0748; Doyle A. Smittle (retired), Department of Horticulture, and Bryan W. Maw, Department of Biological and Agricultural Engineering, Coastal Plain Experiment Station; Ernest W. Tollner, Department of Biological and Agricultural Engineering, Athens; and Yen Con Hung, Department of Food Science and Technology, Georgia Station, Griffin, University of Georgia

\begin{abstract}
Sumner, D. R., Gitaitis, R. D., Gay, J. D., Smittle, D. A., Maw, B. W., Tollner, E. W., and Hung, Y. C. 1997. Control of soilborne pathogenic fungi in fields of sweet onion. Plant Dis. 81:885891.

Populations of soil fungi from fields planted to sweet onion were assayed on selective media. In pathogenicity tests, Rhizoctonia solani AG-4, Pythium irregulare, and Phoma terrestris were the fungi most virulent on onion seedlings. Plots were fumigated with methyl bromide (MBR), chloropicrin $(\mathrm{CP}), \mathrm{MBR}+\mathrm{CP}(67 \%+33 \%)$, metam sodium, 1, 3,-dichloropropene (1,3-D), or $1,3-\mathrm{D}+17 \% \mathrm{CP}$ in four field experiments in 2 years. Sweet onion was transplanted or direct seeded in October or November and harvested in April or May. MBR + CP and CP were effective in reducing populations of Phoma terrestris, Pythium spp., Fusarium spp., and $R$. solani AG-4 in soil. Metam-sodium and 1,3-D + 17\% CP were less efficacious, and MBR and 1,3-D were ineffective. There were no differences in the percentage of bulbs with decay at harvest or after curing among treatments. Increased yield of marketable bulbs was associated with control of soilborne pathogenic fungi. In fields continuously cropped to onion, decreased yield was primarily associated with control of pink-root induced by Phoma terrestris, and P. terrestris was identified in soil from $74 \%$ of the fields assayed.
\end{abstract}

Additional keywords: Aspergillus niger, Botrytis allii

Sweet onion (Allium cepa L.) is grown in many areas of the USA, primarily for fresh market at harvest or for marketing after a few weeks of storage. In Georgia, production has increased steadily from approximately 2,100 ha in 1989 to 5,600 ha in 1995 (5). Because sweet onion is a high-value crop, growers in Georgia frequently plant a monocrop of onion, or double-crop onion with soybean (Glycine $\max ($ L.) Merr.) or other summer crops to allow onion to be grown each year. Numerous diseases of onion are caused by soilborne pathogens $(1,3,4,6,10,25,27)$. Root diseases and bulb rots are of increasing concern to growers in Georgia (23). Soilborne fungi isolated and identified from onion in Georgia include Pythium irregulare Buisman, Rhizoctonia solani Kühn, Rhizoctonia spp., Fusarium spp., F. oxysporum Schlechtend.:Fr. f. sp. cepae (H.N. Hans.) W.C. Snyder \& H.N. Hans, Phoma terrestris E.M. Hans. (syn. Pyrenochaeta terrestris (E.M. Hans.) Gorenz, J.C. Walker, \& R.H. Larson), and Sclerotium rolfsii Sacc. (D. R. Sumner, unpublished).

Corresponding author: D. R. Sumner

E-mail: path2@tifton.cpes.peachnet.edu

Accepted for publication 17 April 1997.

Publication no. D-1997-0527-08R

(C) 1997 The American Phytopathological Society
Soil fumigation is used in some regions to reduce pink-root and other root and bulb diseases of onion $(7,13,17)$, and has been used successfully to control soilborne pathogens in onions grown for transplants and in other vegetables in Georgia $(9,24)$. This research was undertaken to determine the etiology and severity of root and bulb diseases on sweet onion in Georgia, and the influence of soil fumigation on root and bulb diseases, yield, and quality of sweet onion.

\section{MATERIALS AND METHODS}

Soil fumigation. In 1991 and 1992, experiments were established in onion fields on Tifton loamy sand (fine loamy, siliceous, thermic, Plinthic Kandiudults). In 1991, experiments were at Site A, Toombs County, Georgia and Site B, Montgomery County, Georgia. Site A had been in an onion-soybean rotation each year for the previous 5 years, and had a cropping history of onion for at least 20 years. Site B had been in onion-summer fallow for the previous 5 years. A randomized complete block design with three replications was used on each site. Plot size was $5.5 \mathrm{~m}$ wide (three raised beds) by $23 \mathrm{~m}$ long. Plots were fumigated 22 October 1991 by a commercial applicator. Chemicals were injected $20 \mathrm{~cm}$ deep with six chisels spaced $30.5 \mathrm{~cm}$ apart on each raised bed, using a tractor-mounted applicator. Treatments were $67 \%$ methyl bromide $+33 \%$ chloropicrin (MBR-CP33) (87.4 or 126.6 $\mathrm{kg} / \mathrm{ha}) ; 96.5 \%$ CP (84.4 or $123.2 \mathrm{~kg} / \mathrm{ha})$; $98 \% \mathrm{MBR}+2 \% \mathrm{CP}$ (MBR concentrate) (161.3 or $257.6 \mathrm{~kg} / \mathrm{ha})$; or $80 \% 1,3$,-dichloropropene (1,3-D) + 17\% CP (141.5 $\mathrm{kg} / \mathrm{ha}$ ). Plots were not covered with plastic, and the nonfumigated control plots were not covered or chiseled. Immediately after application, plots were irrigated with approximately $1.3 \mathrm{~cm}$ water with overhead sprinklers to seal the soil surface and reduce volatilization of the chemicals.

In 1992, experiments were established at Site $\mathrm{C}$ at the Coastal Plain Experiment Station Horticultural Farm, Tift County, Georgia and at Site D in a field in Tattnall County, Georgia. Site C had been planted to onion for 12 consecutive years, and pink-root was moderate to severe in onions harvested in 1992. At Site D, onions had been grown for at least 3 consecutive years. Plots were fumigated by a commercial applicator on 1 and 22 October, respectively. Plots were $3.66 \mathrm{~m}$ wide (two raised beds) by $15.27 \mathrm{~m}$ long. A randomized complete block design with four replications was used. Treatments were MBRCP33 (126.6 or $392 \mathrm{~kg} / \mathrm{ha})$, CP (123.2 $\mathrm{kg} / \mathrm{ha})$, MBR concentrate (257.6 kg/ha), 1,3-D (113.1 kg/ha) 1,3-D + 17\% CP (177 $\mathrm{kg} / \mathrm{ha})$, metam sodium $(211 \mathrm{~kg} / \mathrm{ha})$ and a nontreated control. Metam sodium was incorporated $15 \mathrm{~cm}$ deep with a tractorpowered Ferguson Tilrovator, and the other fumigants were injected $20 \mathrm{~cm}$ deep with chisels spaced $30.5 \mathrm{~cm}$ apart using a tractor-mounted applicator with a bed shaper. Treated plots were not covered with plastic, and the control plots were not covered or tilled. The experiments were irrigated with $1.3 \mathrm{~cm}$ of water with overhead sprinklers immediately after treatment.

Site $\mathrm{C}$ was irrigated with water from a deep well pumped into a raised holding pond. In contrast, other sites were irrigated from farm ponds that received runoff water from surrounding farmland. Cultivar Granex 33 was used in all experiments. Onions were transplanted (4 rows $15 \mathrm{~cm}$ apart, plants spaced 15 to $20 \mathrm{~cm}$ apart) on 19 and 25 November 1991 at Sites A and $\mathrm{B}$, respectively. In 1992, onion was direct seeded (4 double rows $30 \mathrm{~cm}$ apart, seeds spaced $30 \mathrm{~cm}$ apart, 0.86 $\mathrm{kg} / \mathrm{ha}$ ) at Site C on 13 October, and transplanted at Site D on 24 and 25 November. All transplants were produced by growers in nonfumigated seedbeds, 
and transplants were not evaluated for disease at transplanting.

Soil samples were collected four times from each plot in Sites A and B (10 cores, $2.5-\mathrm{cm}$ diameter, $10 \mathrm{~cm}$ deep): 21 or 22 October (before fumigation), 16 November 1991, and 16 January and 16 March, 1992; three times at Site C: 8 October 1992, and 27 January and 10 March 1993; and three times at Site D: 6 November 1992, and 26 January and 10 March 1993. Soil cores from each plot were mixed thoroughly and assayed for $R$. solani and Rhizoctonia spp. on a modified tannic-acid benomyl medium (22) with a multiple-pellet soil sampler (8), for Pythium spp. on Pimaricin, ampicillin, rifampicin and PCNB (P5ARP) medium (11), on modified PCNB medium for F. solani and total Fusarium spp. (14), and on Ohio Agricultural Experiment Station (OAES) medium for saprophytic fungi (26). Phoma terrestris was assayed on sterile cheesecloth in a medium prepared from $3 \mathrm{~g} \mathrm{NaNO}_{3}, 1 \mathrm{~g} \mathrm{MgSO}_{4}, 0.5$ chloramphenicol, and $20 \mathrm{~g}$ agar in 1 liter of deionized water (21).

Ten plants per plot were removed at random from Sites A and B and rated for external and internal discoloration and decay on 31 March 1992 and at harvest. In Sites $\mathrm{C}$ and $\mathrm{D}$, plant stands were recorded periodically at each site, and 10 to 32 plants were removed for root and bulb disease ratings at each sampling on 17 November 1992, and 17 March and 17 May 1993 at Site C; and on 26 January, 10 March, and 6 May 1993 at Site D. Internal tissues from each bulb were removed aseptically, incubated on water agar, and hyphal tips were transferred to potato dextrose agar (PDA) and identified. Categories established empirically for rating root and bulb discoloration visually were: none (less than $2 \%$ ), slight (2 to $10 \%$ ), moderate (11 to $50 \%$ ), and severe (more than $50 \%$ ).

Bulbs were harvested on 13 April and 22 April 1992 in Site A and Site B, respectively. The middle 3 or $4.6 \mathrm{~m}$ of the middle two rows in the center bed of each plot in Site A and B, respectively, were dug, weighed, and graded. In 1993, onions were harvested on 17 and 6 May in Sites $\mathrm{C}$ and $\mathrm{D}$, respectively. The middle $4.6 \mathrm{~m}$ of the middle two rows of one bed in each plot were dug, weighed, cured and graded. Ten plants from each plot were rated for external discoloration and decay of roots and bulbs. Bulbs were cut aseptically and internal tissues from each bulb were removed, and fungi isolated and identified.

After harvest, bulbs were cured with heated, forced air $\left(37\right.$ to $39^{\circ} \mathrm{C}$ ) for 48 to 72 h. After curing, approximately $10 \mathrm{~kg}$ of bulbs with no external discoloration or decay from each plot were stored at 13 to $24^{\circ} \mathrm{C}, 30$ to $60 \%$ relative humidity, for 8 weeks and evaluated for quality. At 4 and 8 weeks after storage, decayed bulbs were removed, cut aseptically, and fungi isolated from internal tissues. The percentage of marketable bulbs remaining after each storage period was calculated for each treatment.

Pathogenicity tests. Fungi isolated from soil, roots, and bulbs of sweet onions were tested for pathogenicity on slices of sweet onion in petri plates in the laboratory or in soil in a greenhouse. Bulbs with no visible decay were surface disinfected in $0.5 \%$ $\mathrm{NaOCl}$, cut aseptically into slices 5 to 10 $\mathrm{mm}$ thick, and individual slices with no visible discoloration or decay were incubated in autoclaved petri dishes containing moist filter paper. Cultures of fungi were grown on PDA and a 3- to 5-mm block of agar with hyphal tips from each culture was transferred to the center of 2 to 3 onion slices. Petri dishes were incubated 7 to 10 days under fluorescent daylight bulbs (circa 2030 lux), alternating $12 \mathrm{~h}$ light, 12 $\mathrm{h}$ dark, on a bench at 20 to $30^{\circ} \mathrm{C}$, and symptoms were recorded.

In the greenhouse, soil treated $30 \mathrm{~min}$ at 60 to $65^{\circ} \mathrm{C}$ with aerated steam was used. Cultures of fungi were grown 3 to 7 days on PDA, and a 5- to 10-mm block of agar with hyphal tips was transferred to $150 \mathrm{ml}$ of $3 \%$ cornmeal sand in $250 \mathrm{ml}$ Erlenmeyer flasks. Cultures were grown 2 to 3 weeks on cornmeal sand. Soil was blended with commercial fertilizer $(54 \mathrm{mg} / \mathrm{kg} \mathrm{N}$, $\mathrm{K}_{2} \mathrm{O}$, and $\mathrm{P}_{2} \mathrm{O}_{5}$, respectively), infested separately with cultures $(0.1$ to $1 \%$ $\mathrm{vol} / \mathrm{vol}$ ), placed 4 to $10 \mathrm{~cm}$ deep into 5- to 10 -cm-diameter plastic pots or 20 - by 20 $\mathrm{cm}$ aluminum pans, and seeded with onion. Controls were noninfested soil. Pots were placed on a greenhouse bench at temperatures varying from 10 to $30^{\circ} \mathrm{C}$. A randomized complete block design with three or four replications was used in all experiments.

The pathogenicity of eight different isolates of $P$. terrestris was tested on sweet onion cultivar Granex 33, corn (Zea mays L. 'Pioneer 3098' and 'Super Sweet Jubilee'), cucumber (Cucumis sativus L. 'Dasher II'), pearl millet (Pennisetum glaucum (L.) R. Br. 'Tift 23 DB'), soybean ('Deltapine 417'), tomato (Lycopersicon esculentum Miller 'Flora Dade'), and cotton (Gossypium hirsutum L. 'Deltapine 90') in a split-plot experiment. Whole plots were two replications of soil infested with each isolate in 30 - by 60 -cm trays with soil 5 to $7 \mathrm{~cm}$ deep.

Soils from 35 fields with or without a history of onion culture were assayed for Phoma terrestris and Pythium spp. and

Table 1. Populations of fungi in soil and comparisons of interest in an onion field (Site A), Toombs County, Georgia, 1991-1992v

\begin{tabular}{|c|c|c|c|c|c|c|c|c|c|c|}
\hline \multirow[b]{2}{*}{ Treatment $^{w}$} & \multirow[b]{2}{*}{ kg/ha } & \multicolumn{3}{|c|}{$\begin{array}{l}\text { Phoma terrestris } \\
(\text { CFU/g) }\end{array}$} & \multicolumn{3}{|c|}{$\begin{array}{l}\text { Pythium spp. } \\
(\text { CFU/g) }\end{array}$} & \multicolumn{3}{|c|}{$\begin{array}{l}\text { Rhizoctonia solani } \\
\quad(\text { CFU/100 g })^{\mathrm{y}}\end{array}$} \\
\hline & & 15 Nov. & 16 Jan. & 16 Mar. & 15 Nov. & 16 Jan. & 16 Mar. & 15 Nov. & 16 Jan. & 16 Mar. \\
\hline MBR (67\%), CP (33\%) & 87.4 & 0 & 4 & 0 & 6 & 33 & 14 & 2 & 0 & 0 \\
\hline MBR (67\%), CP (33\%) & 126.6 & 0 & 6 & 6 & 3 & 13 & 35 & 0 & 0 & 0 \\
\hline СР $(96.5 \%)$ & 84.4 & 0 & 0 & 3 & 0 & 26 & 104 & 0 & 0 & 0 \\
\hline CP $(96.5 \%)$ & 123.2 & 0 & 0 & 3 & 4 & 1 & 53 & 0 & 0 & 2 \\
\hline MBR $(98 \%)$, CP $(2 \%)$ & 161.3 & 8 & 1 & 14 & 3 & 78 & 118 & 0 & 2 & 0 \\
\hline MBR $(98 \%)$, CP $(2 \%)$ & 257.6 & 11 & 9 & 15 & 2 & 4 & 91 & 12 & 0 & 0 \\
\hline $1,3-\mathrm{D}(80 \%), \mathrm{CP}(17 \%)$ & 141.5 & 11 & 13 & 3 & 7 & 35 & 53 & 10 & 4 & 0 \\
\hline Control & $\ldots$ & 6 & 4 & 6 & 32 & 51 & 107 & 16 & 6 & 0 \\
\hline \multicolumn{11}{|l|}{$\begin{array}{l}\text { Comparisons of interest }^{\mathrm{z}} \\
\text { MBR }(67 \%), \mathrm{CP}(33 \%)\end{array}$} \\
\hline vs. control & & NS & NS & NS & 0.01 & NS & 0.05 & 0.01 & 0.01 & NS \\
\hline $\begin{array}{l}\mathrm{CP}(96.5 \%) \text { vs. control } \\
\mathrm{MBR}(98 \%), \mathrm{CP}(2 \%)\end{array}$ & & 0.01 & NS & NS & 0.01 & 0.05 & NS & 0.01 & 0.01 & NS \\
\hline $\begin{array}{l}\text { vs. control } \\
1,3-\mathrm{D}(80 \%), \mathrm{CP}(17 \%)\end{array}$ & & NS & NS & NS & 0.01 & NS & NS & NS & 0.01 & NS \\
\hline vs. control & & NS & NS & NS & 0.01 & NS & NS & NS & NS & NS \\
\hline
\end{tabular}

${ }^{\mathrm{v}}$ Soil was fumigated 22 Oct. 1991.

${ }^{\mathrm{w}} \mathrm{MBR}=$ methyl bromide, $\mathrm{CP}=$ chloropicrin, $1,3-\mathrm{D}=1,3$-dichloropropene.

${ }^{x} \mathrm{CFU} / \mathrm{g}=$ colonies forming on selective media per gram of soil.

y CFU/100 g = colonies forming on selective media per $100 \mathrm{~g}$ of soil.

${ }^{\mathrm{z}}$ Various linear comparisons were tested with the $F$ test. NS $=$ no significant differences, 0.05 and $0.01=$ levels of significance. 
planted to onion in a greenhouse. In all greenhouse tests, plants were grown for 4 to 8 weeks, dug, washed, and rated for root and stem diseases. Fungi were isolated and identified from selected plants.

Data analysis. Data were analyzed by PROC GLM and PROC STEPWISE statistical analysis programs (16). Fisher's least significant difference or Duncan's multiple range tests were used for means separation. Data were transformed as necessary (square root transformations for small numbers [less than 100], log 10 for large numbers [greater than 100], or arcsine transformations for percents) for statistical analysis (20), but all data are reported as nontransformed values.

\section{RESULTS}

Soil fumigation. Fumigation with MBR-CP33 and 96.5\% CP reduced popu- lations of Phoma terrestris, Pythium spp., and $R$. solani in soil on 15 November at both Sites A and B. MBR concentrate reduced populations of Pythium spp. at Site A, and 1,3-D + 17\% CP was effective against Pythium spp. at both sites, but neither chemical was effective in controlling Phoma terrestris and $R$. solani (Tables 1 and 2). Populations of both fungi were sometimes low or nondetectable, and perhaps more valid comparisons could have been made with higher populations in the controls. The beneficial effects of fumigation with MBR-CP33 and $96.5 \%$ CP could be measured in lowered populations of $R$. solani until the last sampling 16 March.

Fewer than $1 \%$ of the plants in the experiment died after transplanting, and an average of only 1.4 and $1.0 \%$ of the bulbs had internal discoloration and decay on 31 March or at harvest in mid-April at Sites A and $\mathrm{B}$, respectively. Isolations were made from the basal plate or adjacent tissues in 990 plants, and cultures were obtained from $18 \%$ of the plants. The fungi isolated most frequently were $F$. oxysporum $(9.4 \%)$, $F$. moniliforme J. Sheld, (3.0\%), and $F$. subglutinans (Wollenweb. \& Reinking) P.E. Nelson, T.A. Toussoun \& Marasas (2.0\%). Pythium spp., F. solani, and Phoma terrestris were isolated from fewer than $1 \%$ of the plants; $R$. solani AG-4 was not isolated. No pink-root was observed at harvest at Site A, but low levels of pinkroot were present at Site B. Phoma terrestris, Pythium irregulare, F. oxysporum, and Fusarium spp. were isolated from root segments from bulbs with pink-root.

There were no significant differences in yields of marketable onions between each fumigation treatment (rates combined) and the control in paired comparisons at Site A

Table 2. Populations of fungi in soil and comparisons of interest in an onion field (Site B), Montgomery County, Georgia, 1991-1992

\begin{tabular}{|c|c|c|c|c|c|c|c|c|c|c|}
\hline \multirow[b]{2}{*}{ Treatment $^{w}$} & \multirow[b]{2}{*}{$\mathrm{kg} / \mathrm{ha}$} & \multicolumn{3}{|c|}{$\begin{array}{l}\text { Phoma terrestris } \\
(\mathrm{CFU} / \mathrm{g})^{\mathrm{x}}\end{array}$} & \multicolumn{3}{|c|}{$\begin{array}{l}\text { Pythium spp. } \\
(\text { CFU/g) }\end{array}$} & \multicolumn{3}{|c|}{$\begin{array}{l}\text { Rhizoctonia solani } \\
\quad(\text { CFU/100 g) }\end{array}$} \\
\hline & & 15 Nov. & 16 Jan. & 16 Mar. & 15 Nov. & 16 Jan. & 16 Mar. & 15 Nov. & 16 Jan. & 16 Mar. \\
\hline MBR (67\%), CP (33\%) & 87.4 & 1 & 4 & 6 & 14 & 23 & 113 & 0 & 0 & 2 \\
\hline MBR (67\%), CP (33\%) & 126.6 & 0 & 2 & 2 & 0 & 56 & 84 & 2 & 0 & 0 \\
\hline $\mathrm{CP}(96.5 \%)$ & 84.4 & 0 & 2 & 3 & 1 & 15 & 94 & 0 & 0 & 0 \\
\hline $\mathrm{CP}(96.5 \%)$ & 123.2 & 0 & 0 & 0 & 0 & 53 & 85 & 0 & 0 & 0 \\
\hline MBR (98\%), CP (2\%) & 161.3 & 4 & 3 & 8 & 23 & 76 & 102 & 0 & 0 & 4 \\
\hline MBR (98\%), CP (2\%) & 257.6 & 4 & 4 & 10 & 16 & 72 & 218 & 6 & 0 & 9 \\
\hline $1,3-\mathrm{D}(80 \%), \mathrm{CP}(17 \%)$ & 141.5 & 1 & 0 & 3 & 6 & 32 & 48 & 2 & 0 & 2 \\
\hline Control & $\ldots$ & 7 & 0 & 8 & 20 & 103 & 151 & 4 & 4 & 7 \\
\hline \multicolumn{11}{|l|}{ Comparisons of interest $\mathrm{t}^{\mathrm{z}}$} \\
\hline $\begin{array}{l}\text { MBR (67\%), CP (33\%) } \\
\text { vs. control }\end{array}$ & & NS & NS & NS & 0.05 & NS & NS & NS & 0.05 & NS \\
\hline CP $(96.5 \%)$ vs. control & & 0.05 & NS & NS & 0.01 & NS & NS & NS & 0.05 & NS \\
\hline $\begin{array}{l}\text { MBR }(98 \%), \mathrm{CP}(2 \%) \text { vs. } \\
\text { control }\end{array}$ & & NS & 0.05 & NS & NS & NS & NS & NS & 0.05 & NS \\
\hline $\begin{array}{l}1,3-\mathrm{D}(80 \%), \mathrm{CP}(17 \%) \\
\text { vs. control }\end{array}$ & & NS & NS & NS & 0.05 & NS & NS & NS & NS & NS \\
\hline
\end{tabular}

v Soil was fumigated 22 Oct. 1991.

${ }^{\mathrm{w}} \mathrm{MBR}=$ methyl bromide, $\mathrm{CP}=$ chloropicrin, 1,3-D = 1,3-dichloropropene.

$\mathrm{x} \mathrm{CFU} / \mathrm{g}=$ colonies forming on selective media per gram of soil.

${ }^{\mathrm{y}} \mathrm{CFU} / 100 \mathrm{~g}=$ colonies forming on selective media per $100 \mathrm{~g}$ of soil.

z Various linear comparisons were tested with the $F$ test. NS $=$ no significant differences, 0.05 and $0.01=$ levels of significance.

Table 3. Sweet onion yield, bulb rot at harvest, and comparisons of interest after different preplant soil fumigation treatments in Toombs and Montgomery Counties, Georgia, 1992 and 1993

\begin{tabular}{|c|c|c|c|c|c|c|}
\hline \multirow[b]{2}{*}{ Treatment $^{\mathrm{x}}$} & \multirow[b]{2}{*}{$\mathrm{kg} / \mathrm{ha}$} & \multicolumn{3}{|c|}{ Site A } & \multicolumn{2}{|c|}{ Site B } \\
\hline & & Yield (kg/ha) & $\operatorname{Jumbos}^{\mathrm{y}}(\%)$ & Decayed bulbs (\%) & Yield (kg/ha) & Jumbos $(\%)$ \\
\hline \multirow[t]{2}{*}{$\overline{\mathrm{MBR}}(67 \%), \mathrm{CP}(33 \%)$} & 87.4 & 26,880 & 23 & 0.7 & 35,840 & 92 \\
\hline & 126.6 & 35,840 & 8 & 0 & 34,216 & 90 \\
\hline \multirow[t]{2}{*}{ CP $(96.5 \%)$} & 84.4 & 27,776 & 17 & 0.7 & 33,712 & 89 \\
\hline & 123.2 & 35,952 & 15 & 0 & 33,544 & 90 \\
\hline \multirow{2}{*}{ MBR (98\%), CP (2\%) } & 161.3 & 30,744 & 13 & 0 & 30,632 & 86 \\
\hline & 257.6 & 29,456 & 8 & 0 & 32,088 & 91 \\
\hline 1,3-D (80\%), CP (17\%) & 141.6 & 31,864 & 18 & 0 & 29,400 & 85 \\
\hline Control & & 27,328 & 8 & 0 & 32,008 & 87 \\
\hline \multicolumn{7}{|l|}{ Comparisons of interest ${ }^{\mathrm{z}}$} \\
\hline MBR (67\%), CP (33\%) vs. control & & NS & & & NS & \\
\hline CP $(96.5 \%)$ vs. control & & NS & & & NS & \\
\hline MBR (98\%), CP (2\%) vs. control & & NS & & & NS & \\
\hline 1,3-D (80\%), CP (17\%) vs. control & & NS & & & NS & \\
\hline
\end{tabular}

$\mathrm{x} \mathrm{MBR}=$ methyl bromide, $\mathrm{CP}=$ chloropicrin, $1,3-\mathrm{D}=1,3$-dichloropropene.

y Bulbs $>7.0 \mathrm{~cm}$ diameter.

$\mathrm{z}$ Various linear comparisons were tested with the $F$ test. NS $=$ no significant differences. 
or B (Table 3). However, yields of marketable onions were greater $(P=0.05)$ in plots fumigated with the highest rates of $\mathrm{CP}$ and MBR-CP33 compared with control plots at Site A. Differences may have been related to fewer plants bolting (producing seed heads, data not shown) in plots fumigated with MBR-CP33 and the high rates of CP. Bulbs from plants that bolt are nonmarketable.

Soil fumigation treatments with MBRCP33 (392 kg/ha), metam sodium, and CP $(123.2 \mathrm{~kg} / \mathrm{ha})$ were the most effective in reducing populations of soil fungi at both
Sites C and D. MBR-CP33 (126.6 kg/ha) and $1,3-\mathrm{D}+17 \% \mathrm{CP}$ were less effective, and 1,3-D alone and MBR concentrate were ineffective, compared with no fumigation. Comparison of MBR-CP33 (392 $\mathrm{kg} / \mathrm{ha}$ ) with two fumigants used occasionally in onion fields in Georgia, metam
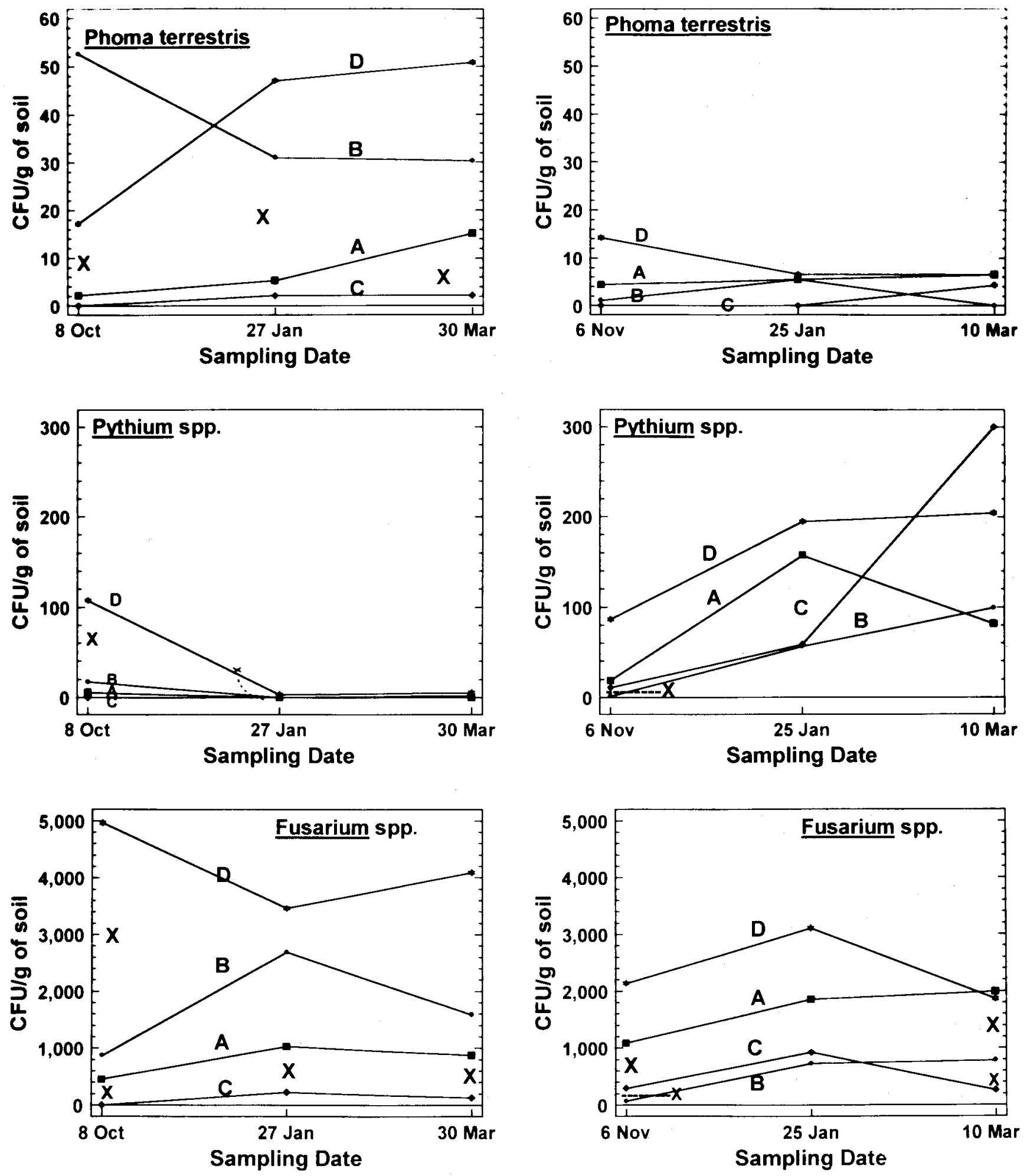

Fig. 1. Populations of Pythium spp., Phoma terrestris, and Fusarium spp. in CFU/g of oven-dried soil in field plots fumigated with 80\% 1,3-dichloropropene $+17 \%$ chloropicrin $(177 \mathrm{~kg} / \mathrm{ha})(\mathbf{A})$, metam sodium $(211 \mathrm{~kg} / \mathrm{ha})(\mathbf{B}), 67 \%$ methyl bromide $+33 \%$ chloropicrin $(392 \mathrm{~kg} / \mathrm{ha})(\mathbf{C})$, or nonfumigated (D) Plots were fumigated on 1 and 22 October 1992, in Tift County (Site C, left graphs) and Tattnall County (Site D, right graphs) in Georgia. Onion was direct seeded in Site A on 13 October and transplanted in Site D on 24 and 25 November, respectively. An "X" between treatments at a specific date indicates a significant difference, $P=0.05$. 
sodium and 1,3-D + 17\% CP, are shown in Figure 1. Populations of Pythium spp., Phoma terrestris, and Fusarium spp. in soil from 8 to 15 days after fumigation through March 1993 at both Sites C and D are illustrated.

Populations of Phoma terrestris were very high in the controls and were reduced greatly by $1,3-\mathrm{D}+17 \% \mathrm{CP}$ and MBRCP33 (392 kg/ha) at Site C. In contrast, populations in the controls at Site D were lower, and soil fumigation did not reduce populations significantly $(P=0.05)$. All three soil fumigation treatments eliminated or greatly reduced populations of Pythium spp. at Site C, and propagules were nondetectable in most plots on 27 January and 30 March. At Site D, only soil fumigation with MBR-CP33 (392 kg/ha) reduced populations of Pythium spp. initially. On 25 January and 10 March, populations were high and not different among treatments. Metam sodium and MBR-CP33 $(392 \mathrm{~kg} / \mathrm{ha})$ reduced populations of Fusarium spp. at both sites, but 1,3-D + $17 \% \mathrm{CP}$ reduced populations significantly only at Site D. MBR-CP33 (392 kg/ha) gave greater initial control than metam sodium at Site C, but the reverse was true at Site D. MBR-CP33 (392 kg/ha) gave full-season control, and was superior to the other soil fumigants at both locations in March.

There were no differences in plant stands in Site C until 4 months after planting, when the number of plants in plots treated with $1,3-\mathrm{D}+17 \% \mathrm{C}$ was increased significantly compared with nonfumigated plots. Post-emergence damping-off averaged 3.2\% for all treatments in Site D, and plant stands were not increased by soil fumigation. At Site C, $17.8 \%$ of the plants in the control had slight root and basal plate discoloration on 17 November, more $(P=0.05)$ than in the fumigated treatments (average $3.9 \%$ ), but no discoloration was observed in plants sampled on 30 March. In contrast, $52 \%$ of the plants (average of all treatments) had symptoms of pink-root at harvest on 17 May, and 8\% had moderate root disease. Isolations were made from the roots or basal plate of 1193 plants, and cultures were obtained from $41 \%$ of the plants. The fungi isolated most frequently on water agar were $F$. oxysporum $(24.3 \%)$, F. solani (5.4\%), and Fusarium spp. (2.8\%). Pythium spp. and Phoma terrestris were isolated from $1 \%$ or less of the plants; $R$. solani AG-4 was not isolated.

There was an average of 13 and $21 \%$ tion or decay in plants in the control 9 or 15 weeks after transplanting in Site D, respectively. Soil fumigation did not improve plant health. Symptoms of pink-root at Site D were observed on fewer than $1 \%$ of plants on 27 January and 10 March, and only on $15 \%$ of plants in the control at harvest. Plants with moderate root and bulb discoloration and decay averaged 1 to $2 \%$ on 25 January, 10 March, at harvest, and after curing. There were no significant differences among treatments in symptoms of pink-root or root and bulb discoloration and decay. Fungi were isolated from roots or basal plates of 1215 plants, and cultures were recovered from $87 \%$ of the plants. $F$. oxysporum (56.9\%), Pythium irregulare, and Pythium spp. (26.1\%) were isolated most frequently; Phoma terrestris and $R$. solani AG-4 were not isolated.

All soil fumigation treatments increased yield of marketable bulbs at Site C, but not at Site D (Table 4). From harvest until after curing, an average of 6 and $2 \%$ of the bulbs decayed from Sites C and D, respectively (3\% in the controls at both locations). There were no significant differences in decay of bulbs during curing among treatslight or moderate root and bulb discolora-

ments. The fungi isolated most frequently from bulbs selected at random at harvest from both sites were Fusarium spp. (primarily $F$. oxysporum), but Penicillium spp. and Pythium spp. (primarily P. ir regulare) were isolated from 8 and $7 \%$ of the bulbs in Site D (Table 5). After 4 and 8 weeks of storage, Botrytis spp. (primarily $B$. allii Munn) were isolated most frequently from decayed bulbs from both sites, and Aspergillus niger Tiegh. was isolated frequently at Site $\mathrm{C}$ at 4 weeks and infrequently at 8 weeks after storage (Table $5)$.

There were no differences $(P=0.05)$ among treatments in the frequency of fungi isolated, nor in the percentage marketable bulbs after 4 weeks in storage at either site. After bulbs from Site D were stored 8 weeks, there were more $(P=0.05)$ marketable bulbs in the control than in the MBRCP (392 kg/ha) treatment (79 vs. $54 \%$ ); other treatments were not different from the control. There were no differences $(P=$ $0.05)$ in marketable bulbs 8 weeks after bulbs from Site $\mathrm{C}$ were placed in storage.

Pathogenicity tests. On onion slices, isolates were considered slightly, moderately, or highly virulent if they caused 0.1 to $0.4,0.5$ to 1.0 , or more than $1.0 \mathrm{~cm}^{3}$ discoloration or decay, respectively, after incubation for 1 week at 23 to $34^{\circ} \mathrm{C}$. The number of isolates tested is listed in parenthesis following each fungus. Sclerotium rolfsii (3), A. niger (3), Pythium irregulare (2), and $R$. solani AG-4 (3), in

Table 5. Fungi (\%) isolated from onion bulbs in Tift (Site C) and Tattnall (Site D) counties, Georgia at harvest and after storage for 4 and 8 weeks at 13 to $24^{\circ} \mathrm{C}$, and 30 to $60 \%$ relative humidity, 1993

\begin{tabular}{lrrrrrrr}
\hline & \multicolumn{3}{c}{ Site $\mathbf{C}$} & & \multicolumn{3}{c}{ Site D } \\
\cline { 2 - 4 } \cline { 6 - 8 } Fungi & $\mathbf{0}^{\mathbf{y}}$ & $\mathbf{4}^{\mathbf{z}}$ & $\mathbf{8}^{\mathbf{z}}$ & & $\mathbf{0}^{\mathbf{y}}$ & $\mathbf{4}^{\mathbf{z}}$ & $\mathbf{8}^{\mathbf{z}}$ \\
\hline Botrytis allii & 0 & 36 & 58 & & 0 & 49 & 64 \\
Penicillium spp. & 0 & 11 & 20 & & 8 & 10 & 25 \\
Fusarium oxysporum & 22 & 0 & 2 & & 60 & 3 & 6 \\
Fusarium solani & 7 & 0 & 0 & & 0 & 0 \\
Total Fusarium spp. & 31 & 2 & 2 & & 63 & 3 & 6 \\
Aspergillus niger & 2 & 19 & 5 & & 0 & 0 & 0 \\
Pythium spp. & 1 & 0 & 0 & & 7 & 0 & 0 \\
Sclerotium rolfsii & 0 & 2 & 0 & & 0 & 0 & 0 \\
\hline
\end{tabular}

${ }^{y}$ At harvest, fungi isolated from 10 bulbs selected at random from each fumigated plot in each experiment ( 320 bulbs).

${ }^{z}$ Fungi isolated from decayed bulbs, 47 to 206 bulbs per sampling, average of all treatments.

Table 4. Yield of marketable onions in field plots treated with different soil fumigants in Tift and Tattnall counties, Georgia, 1993

\begin{tabular}{|c|c|c|c|c|c|}
\hline \multirow[b]{2}{*}{ Treatment $^{\mathrm{x}}$} & \multirow[b]{2}{*}{$\mathrm{kg} / \mathrm{ha}$} & \multicolumn{2}{|c|}{ Site C } & \multicolumn{2}{|c|}{ Site D } \\
\hline & & Total (kg/ha) & Jumbos $^{\mathrm{y}}$ (kg/ha) & Total (kg/ha) & Jumbos $^{y}(\mathrm{~kg} / \mathrm{ha})$ \\
\hline \multirow{2}{*}{$\overline{\mathrm{MBR}(67 \%), \mathrm{CP}(33 \%)}$} & 126.6 & $47,980{b c^{2}}^{2}$ & $38,153 \mathrm{bc}$ & 34,832 & 27,216 \\
\hline & 392.0 & $52,965 \mathrm{ab}$ & $45,584 \mathrm{ab}$ & 36,120 & 25,144 \\
\hline $\mathrm{CP}(96.5 \%)$ & 123.2 & $48,802 \mathrm{c}$ & $38,808 \mathrm{bc}$ & 37,968 & 27,048 \\
\hline MBR (98\%), CP (2\%) & 257.6 & $45,892 \mathrm{c}$ & $36,512 \mathrm{~cd}$ & 34,104 & 20,272 \\
\hline $1,3-\mathrm{D}(80 \%)$ & 113.1 & $49,465 \mathrm{abc}$ & $43,792 \mathrm{abc}$ & 39,144 & 26,488 \\
\hline $1,3-\mathrm{D}(80 \%), \mathrm{CP}(17 \%)$ & 177.0 & $48,143 \mathrm{bc}$ & $39,984 \mathrm{abc}$ & 38,640 & 28,224 \\
\hline Metam sodium & 236.3 & $55,238 \mathrm{a}$ & $47,488 \mathrm{a}$ & 34,944 & 24,472 \\
\hline Control & $\ldots$ & $37,453 \mathrm{~d}$ & $29,400 \mathrm{~d}$ & 33,600 & 19,880 \\
\hline
\end{tabular}

$\times \mathrm{MBR}=$ methyl bromide, $\mathrm{CP}=$ chloropicrin, $1,3-\mathrm{D}=1,3$-dichloropropene.

y Bulbs $\geq 7.0 \mathrm{~cm}$ diameter.

z Numbers followed by the same letter are not significantly different according to Fisher's least significant difference, $P=0.05$. No letters indicates no significant differences. 
order, caused the most decay (4 to $58 \mathrm{~cm}^{3}$ ). Twenty-five isolates of $F$. oxysporum were moderately to highly virulent, while 16 isolates were slightly virulent to avirulent. Isolates of $F$. moniliforme (11) and $F$. subglutinans (8), and Phoma terrestris (4) were avirulent to slightly virulent, and $F$. solani (8), and unidentified Pythium spp. (2), and Phoma spp. (3) were avirulent.

In greenhouse experiments, pathogens were rated as being slightly (less than $10 \%$ ), moderately (11 to $50 \%$ ), or highly (more than 50\%) virulent based on the discoloration and decay of roots and lower stems. The pathogens most virulent on onion seedlings in greenhouse experiments were $R$. solani AG-4 (1), Pythium irregulare (6), P. terrestris (15), and F. oxysporum (6), in order. F. solani (1) and Rhizoctonia spp. CAG-5 (AG-R) (3) and CAG-2 (AG-A) (1) were avirulent. In tests in environmental chambers, isolates of $R$. solani AG-1 (1), AG 2-1 (2), and AG 2-2 IIIB (1), and binucleate Rhizoctonia spp. CAG-3 (AG-E) (3), CAG-4 (AG-F) (1), and CAG-5 (1) were avirulent and $R$. solani AG-4 (1) was virulent at diurnal temperature ranges of both 10 to 21 and 21 to $32^{\circ} \mathrm{C}$.

Phoma terrestris induced pink-root in onion, a pinkish cast in tomato and cucumber roots, pink to black lesions and discoloration on field corn roots and pink to violet discoloration of sweet corn seeds. The pathogen caused gray-black roots in soybean, pinkish-black to black root and mesocotyl lesions in pearl millet, and black lesions on cotton tap roots. The pathogen was reisolated from roots of all crops except tomato and cotton.

Phoma terrestris and Pythium spp. were detected in 74 and $91 \%$ of the assays of soil samples collected in fields, respectively, but $R$. solani was detected infrequently. In two experiments with soils collected from 19 and 17 different fields, respectively, populations of Phoma terrestris in soil were correlated significantly $(P=0.05)$ with a decrease in plant stand of onion in the greenhouse ( $r=0.41$ and 0.32 , respectively). In the second experiment, plant stands were correlated negatively with a cropping history of 2 years of onion $(r=-0.38)$, and positively with a history of no onion production during the previous 2 years $(\mathrm{r}=0.52)$. Populations of Pythium spp. and $R$. solani AG-4 in soil were not correlated with plant stand.

\section{DISCUSSION}

While many soilborne fungi occurring naturally in fields of sweet onion in Georgia are pathogenic to onion, yields of marketable bulbs were increased only in a field (Site C) planted to onion continuously that was highly infested with Phoma terrestris. In Colorado, soil fumigation for onion production was beneficial only when pinkroot and Fusarium root diseases were moderate to severe (17). We found the greatest yield response to soil fumigation in our experiments where pink-root and other root decay symptoms were visible in $18 \%$ of the plants in the control 5 weeks after planting.

The pink-root pathogen was detected in soil in $74 \%$ of the onion fields assayed. As intensive onion culture continues, most fields will probably become infested. Soybean, corn, pearl millet, and other crops that may be rotated with onion are susceptible in Georgia and other onion regions (13). Thus, the inoculum density of Phoma terrestris may remain high in infested fields even with crop rotation, and the pathogen is known to survive to a depth of $46 \mathrm{~cm}$ (19). Pink-root may be more widespread in Georgia than we have observed, as some isolates of the pathogen do not cause typical pink discoloration in onion roots (2).

In Georgia, onions are direct seeded into seedbeds in August and September when soil temperatures $3 \mathrm{~cm}$ deep range from 25 to $40^{\circ} \mathrm{C}$, and seedlings are transplanted into fields in November and December when soil temperatures range from 10 to $25^{\circ} \mathrm{C}$. Thus, soil temperatures are much more favorable for infection of onion roots by $P$. terrestris in seedbeds than for infection of roots of transplants in fields during the late fall and winter (6). However, soil temperatures in the spring are favorable for the growth of the pathogen during the few weeks before harvest.

This research corroborates previous research in Georgia (9) and in other oniongrowing regions $(7,15)$ that soil fumigants are effective in reducing the inoculum density of soilborne pathogens in soil planted to onion, and indicates the potential threat of $P$. terrestris to the sweet onion industry. Though pink-root is the most severe root pathogen in transplanted onion, Pythium spp., $R$. solani AG-4, and Fusarium spp. may reduce the production of healthy plants in seedbeds. Since many growers use the same fields for seedbeds year after year, soil fumigation may become an essential annual practice for seedbed preparation. In our research, fumigation with metam sodium $(211 \mathrm{~kg} / \mathrm{ha})$ and 1,3-D + 17\% CP (177 kg/ha) were viable alternatives to fumigation with materials containing methyl bromide in a field cropped continuously to sweet onion. More research is necessary to determine what soil fumigation treatments will be the most efficacious and economical for control of Phoma terrestris and other pathogens. However, for soil fumigation to be effective, pathogens should be excluded as long as possible after fumigation. Pathogens can be reintroduced into fumigated soil in contaminated irrigation water (18). Some onion growers use water from farm ponds receiving runoff water from surrounding fields; therefore, growers who invest in soil fumigation should also invest in developing holding ponds for clean water from irrigation wells.

Soil solarization has been used effectively to reduce populations of soilborne pathogens, including $P$. terrestris, in Israel (12) and Australia (15). In Georgia, the only time soil temperatures are high enough for effective solarization is in July and August, so a summer rotation crop could not be grown if solarization was used. Also, soil temperatures may not be increased enough to make solarization feasible in Georgia when summers are wet. More research on soil solarization is necessary before the practice can be recommended to growers of sweet onions in Georgia.

\section{ACKNOWLEDGMENTS}

This research was supported by state and Vidalia Onion Committee funds allocated to the Georgia Agricultural Experiment Stations. We thank Ben Mullinix for assistance in statistical analysis.

\section{LITERATURE CITED}

1. Abawi, G. S., and Lorbeer, J. W. 1972. Several aspects of the ecology and pathology of Fusarium oxysporum f. sp. cepae. Phytopathology 62:870-876.

2. Biles, C. L., Holland, M., Ulloa-Godinez, M. Clason, D., and Corgen, J. 1993. Pyrenochaeta terrestris microsclerotia production and pigmentation on onion roots. HortScience 27:1213-1216.

3. Bruckart, W. L., and Lorbeer, J. W. 1982. Pythium species pathogenic to onion seedlings grown on organic soils in New York. Phytopathology 72:469-475.

4. Gaur, R. B., and Agnthotri, J. P. 1979. Root rot of onion caused by Fusarium solan (Mart.) Sacc. Madras Agric. J. 66:837-838.

5. Georgia Agricultural Statistics Service. 1995. Georgia Agricultural Facts. Ga. Agric. Statistics Service, Athens, GA.

6. Gorenz, A. M., Larson, R. H., and Walker, J. C. 1949. Factors affecting pathogenicity of pink root fungus of onions. J. Agric. Res. 78:1-18.

7. Hartz, T. K., Bogle, C. R., Bender, D. A., and Avila, F. A. 1989. Control of pink root disease in onion using solarization and fumigation. $\mathrm{J}$ Amer. Soc. Hortic. Sci. 114:587-590.

8. Henis, Y., Ghaffar, A., Baker, R., and Gillespie, S. L. 1978. A new pellet soil-sampler and its use for the study of population dynamics of Rhizoctonia solani in soil. Phytopathology 68:371-376.

9. Jaworski, C. A., McCarter, S. M., Johnson, A. W., and Williamson, R. E. 1978. Response of onions grown for transplants to soil fumigation. J. Am. Soc. Hortic. Sci. 103:385-388.

10. Jeffe, A. Z., Ausher, R., and Palti, J. 1972 Distribution and pathogenicity of Fusarium species associated with onion in Israel. Phytopathol. Mediterr. 11:159-162.

11. Jeffers, S. N., and Martin, S. B. 1986. Comparison of two media selective for Phy tophthora and Pythium species. Plant Dis. 70:1038-1043.

12. Katan, J. Rotem, I., Finkel, Y., and Daniel, J. 1980. Solar heating of the soil for the control of pink root and other soilborne diseases of onions. Phytoparisitica 8:39-50.

13. Kreutzer, W. A. 1941. Host-parasite relationships in pink root of Allium cepa II. The action of Phoma terrestris on Allium cepa and other hosts. Phytopathology 31:907-915.

14. Papavizas, G. C. 1967. Evaluation of various media and antimicrobial agents for isolation of Fusarium from soil. Phytopathology 57:848-852. 
15. Porter, I. J., Merriman, P. R., and Keane, P. T. 1989. Integrated control of pink root (Pyrenochaeta terrestris) of onions by dazomet and soil solarization. Aust. J. Agric. Res. 40:861-869.

16. SAS Institute. 1985. SAS Users Guide: Statistics Version, 5th edition. SAS Inst. Inc., Cary, NC.

17. Schwartz, H. F., and McMillan, M. S. 1987. Onion disease management research in Colorado. Pages 62-65 in: Proc. Nat. Onion Res. Conf., Denver, Colorado.

18. Shokes, F. M., and McCarter, S. M. 1979. Occurrence, dissemination, and survival of plant pathogens in surface irrigation ponds in southern Georgia. Phytopathology 69:510516
19. Siemer, S. R., and Vaughan, E. K. 1971. Bioassay of Pyrenochaeta terrestris inoculum in soil. Phytopathology 61:146-148.

20. Steel, R. G. D., and Torrie, J. H. 1960. Principles and procedures of statistics. McGrawHill Book Co., Inc., New York.

21. Strobel, N. E., and Lorbeer, J. W. 1990. A novel differential medium for the quantification of Phoma terrestris in organic soils. (Abstr.) Phytopathology 80:1008

22. Sumner, D. R., and Bell, D. K. 1982. Root diseases of corn induced by Rhizoctonia solani and Rhizoctonia zeae. Phytopathology 72:86-91.

23. Sumner, D. R., and Gay, J. D. 1984. Basal rot of onion caused by Fusarium oxysporum $\mathrm{f}$. sp. cepae in Georgia. Plant Dis. 68:450.
24. Sumner, D. R., Johnson, A. W., Jaworski, C. A., and Chalfant, R. B. Influence of film mulches and soil pesticides on root diseases and populations of soil-borne fungi in vegetables. Plant Soil 49:267-283.

25. Vincelli, P. C., and Lorbeer, J. W. 1990. Root rot of onion caused by Pythium irregulare and Pythium coloratium. Mycopathologia 111:6772.

26. Williams, L. E., and Schmitthenner, A. F. 1960. Effect of growing crops and crop residues on soil fungi and seedling blights. Phytopathology 50:22-25.

27. Winstead, N. N., Strider, D. L., and Person, L. H. 1960. Vegetable diseases in North Carolina during 1958 and 1959. Plant Dis. Rep. 44:491-495. 